\title{
Enhancement of Phosphorus Uptake, Growth and Yield of Sweet Potato (Ipomoea Batatas) with Phosphorus Fertilizers
}

\author{
*11KAREEM, I; ${ }^{2}$ AKINRINDE, EA; ${ }^{3}$ OLADOSU, Y; ${ }^{1}$ EIFEDIYI, EK; ${ }^{4}$ ABDULMALIQ, \\ SY; ${ }^{1}$ ALASINRIN, SY; ${ }^{5}$ KAREEM, SA; ${ }^{5}$ ADEKOLA, OF \\ ${ }^{*}$ Department of Agronomy, University of Ilorin, P. M. B. 1515, Ilorin, Nigeria \\ ${ }^{2}$ Department of Agronomy, University of Ibadan, Ibadan, Nigeria \\ ${ }^{3}$ Institute of Tropical Agriculture, Universiti Putra Malaysia, 43400 Serdang, Selangor, Malaysia \\ ${ }^{4}$ Department of Crop Production, Ibrahim Badamasi Babangida Univesity, Lapai, Niger State, Nigeria \\ ${ }^{5}$ Department of Biology, School of Secondary Education (Science Programme), Federal College of Education (Special), Oyo, Nigeria. \\ *Corresponding Author Email address-abdulkareemishaaq@gmail.com; Tel: +2348032454636
}

\begin{abstract}
This research was carried out to determine the best phosphorus fertilizer for improvement of sweet potato phosphorus uptake, growth and yield. The phosphorus fertilizer sources used were organic (Pacesetter), single super phosphate and crystallizer while the sweet potato variety used was Shaba. The experiment was laid out in randomized complete block design (RCBD) with three replications. Sweet potato plants from plots treated with crystallizer fertilizer at the rate of $500 \mathrm{~kg} / \mathrm{ha}$ had the highest phosphorus uptake and vegetative growth while control plots produced plants with highest tuberous yield. It is, therefore, recommended that crystallizer applied at the rate of $500 \mathrm{~kg} / \mathrm{ha}$ be used for significant phosphorous uptake which equally leads to better quality sweet potato tuber and appreciable vegetative growth. It is also recommended that the soil phosphorus be maintained at low level around $6.80 \mathrm{mg} / \mathrm{kg}$ for achievement of high tuberous yield in sweet potato.
\end{abstract}

\section{DOI: $\underline{\text { https://dx.doi.org/10.4314/jasem.v24i1.11 }}$}

Copyright: Copyright (C) 2020 Kareem et al. This is an open access article distributed under the Creative Commons Attribution License (CCL), which permits unrestricted use, distribution, and reproduction in any medium, provided the original work is properly cited.

Dates: Received: 30 November 2019; Revised: 20 December 2019; Accepted: 23 December 2019

Keywords: Vegetative growth, yield, phosphorous uptake, phosphorous fertilizers

Sweet potato (Ipomoea batatas) belongs to the family Convolvulaceae. It is becoming the most widely distributed root crop in most developing countries. Sweet potato (Ipomoea batatas L.) is a foremost tuber crop in respect of calorific value and is grown in almost all soil types in most parts of the tropics and warm temperate regions. Globally, it is among the important food crops which are wheat, rice, maize, irish potato and barley and it ranks second among the world's production of root and tuber crops and third in consumption in several parts of tropical Africa (Lenne, 1991). It has been established that sweet potato is more nutritious and flavourful. Therefore, it should be grown in greater quantities. It is also an excellent source of complex carbohydrates, high antioxidants, vitamins (A and $\mathrm{C}$ ), phosphorus, potassium, magnesium, calcium, sulfur, iron, manganese, copper, boron, zinc, iodine, folic acid, cystine fiber, starch, protein, niacin, tryptophan and tyrosine. The starch in sweet potato easily converts to sugar and provides quick energy. So, it is actually a super food (Griffiths and Lunec, 2001). The consumption of sweet potato is in different forms. It can be consumed as vegetable, boiled, fried as chips, backed, roasted or often fermented into food and beverages. Phosphorus is one of the main nutrients for most plant species including sweet potato plants (Ipomoea batatas, L.). The necessity of phosphorus as a plant nutrient is emphasized by the fact that it is an essential constituent of many organic compounds that are very important for metabolic processes and root development (Purekar et al., 1992). In the same vein,neither plant nor animals can grow without phosphorus because it is an essential component of the energy currency of the living cell: Adenosine Triphosphate (ATP) as well as deoxyribonucleic acid (DNA) which the seat of genetic inheritance. It equally forms an essential part of ribonucleic acid (RNA) which is responsible for directing protein synthesis in both plants and animals. Moreover, phospholipids which play critical roles in cellular membranes are another class of universally important phosphoruscontaining compounds. Furthermore, adequate phosphorus nutrition enhances many aspects of plant physiology like fundamental process of photosynthesis, nitrogen fixation, flowering, fruiting (including seed production) and maturation. Root growth, particularly development of lateral roots and 
fibrous rootlets, is also encouraged by phosphorus. In cereal crops, good phosphorus nutrition strengthens structural tissues such as those found in straw or stalk, thus helping in prevent lodging (falling over). Improvement of crop quality, especially in forages and vegetables, is another benefit attributed to this nutrient. As important as this nutrient element is, its total content in the healthy leaf tissue of most plant species is not high and usually ranges between $0.2 \%$ and $0.4 \%$ of the dry matter (Nyle and Ray, 1999).

Fortification of cow dung with NPK fertilizer in sweet potato production will lead to higher nutrient uptake of which phosphorus is a part. This consequently leads to resultant increase in crop yield. This increase in yield has been attributed to the significant increase in $\mathrm{P}, \mathrm{K}$ and $\mathrm{Ca}$ uptake by sweet potato (Forbes and Watson, 1994). Since phosphorus is not as mobile as nitrogen and potassium, some available phosphorus which is not used up by sweet potato may not experience leaching (Fixen and Vivekananda, 1990).

It has been estimated that nearly 36.78 million tonnes of P-based fertilizers (in terms of $\mathrm{P}_{2} \mathrm{O}_{5}$ ) are applied worldwide every year (International Fertiliser Industry Association, 2006). However, the use efficiency of applied $\mathrm{P}$ is generally very low ranging from 10 to $30 \%$ in the year of application (McLaughlin et al., 1991). In most soils, in spite of the considerable addition of P-fertilizers, the amount of $\mathrm{P}$ available for plants is usually low since it is converted to unavailable form by its reaction with the soil constituents (Marschner H (1995). Despite this, EIGamal and Abdel-Nasser (1996) still reported that Pfertilizer application positively increased sweet potato productivity compared with the untreated control. These increments were attributed to the beneficial effect of $\mathrm{P}$ element on the activation of photosynthesis and metabolic processes of organic compounds in plants and hence increase in plant growth (Purekar et al., 1992). The increment was also attributed to the important role of phosphorus as an essential component of many organic compounds in plants such as phospholipids, nucleic acids and nucleotides which may indirectly reflect positively on yield (McLaughlin et al., 1991). Similarly, Abdel-Hamed (1997) also found that fertilization of sweet potato plants with $\mathrm{P}$ fertilizer caused significant increase in total and marketable yield. Because phosphorus is an essential element in the energy transfer processes, formation of fat, transformation of starch to sugar, flowering and fruiting stage of the crop, it is considered one of the major growth-limiting factors for plants in many natural ecosystems. Combating the problem of limitation posed by phosphorus nutrition, plants have developed several adaptive mechanisms to overcome its stress (Marschner, 1995).

Since an appreciable level of phosphorus can greatly improve the quality of root and tuber crops as well as their shelf lives, the present research was, therefore, carried out to determine the best phosphorus fertilizer for improvement of sweet potato phosphorus uptake, growth and yield.

\section{MATERIALS AND METHODS}

This research was carried out at the Teaching and Research Farm of Agronomy Department, University of Ibadan at Parry Road, Ibadan, Oyo $\operatorname{State}\left(7.27^{\circ} \mathrm{N}\right.$ $3.54^{\circ} \mathrm{E}$ ). The temperature ranges between $22^{\circ} \mathrm{C}$ and $28^{\circ} \mathrm{C}$ with annual rainfall between $1000 \mathrm{~mm}$ and $1600 \mathrm{~mm}$. The soil type was sandy loam with a very low level of phosphorus $(6.80 \mathrm{mg} / \mathrm{kg})$.

After preparation of the field, the area was divided into twelve plots. Soil samples were taken from each plot, air dried on sheets of paper under shade and passed through a $2 \mathrm{~mm}$ sieve. The samples were finally put in new bower vessels and kept in the laboratory for application of treatments and observation of the amount of phosphorus that could be released into the soil with time passage. Each bower vessel in the laboratory represented a plot on the field. Each soil sample in the vessels was given the same treatment as applied on the field. The soil samples were then supplied with water up to $60 \%$ field capacity and left in the laboratory for phosphorus release to occur. At the end of the first week, a sample was taken from each of the bower vessels. The samples were air-dried under shade on sheets of paper and then analyzed for phosphorus content. This exercise was embarked upon for five consecutive weeks. At the end of sample collection, available phosphorus was extracted by Bray No 1 method, and its determination was done using molybdenum blue method (Kuo, 1996).

On the field, $25 \mathrm{~cm}$ length of sweet potato vines of Shaba variety were planted at an angle of $45^{\circ}$ with two thirds of the vine under the soil for proper establishment. The plant spacing used was $30 \mathrm{~cm}$ by $100 \mathrm{~cm}$ with a total of 18 plants per plot. Four treatments with three replications were used in this experiment. The design of the experiment was Randomized Complete Block (RCB). At the end of fifth week after planting, thre four treatments were applied as follows: treatment 1(control), treatment 2(Pacesetter organic fertilizer at the rate of $5 \mathrm{t} / \mathrm{ha}$ ), treatment 3 (Single super phosphate at the rate of 500 $\mathrm{kg} / \mathrm{ha}$ ) and treatment 4 (crystallizer at the rate of $500 \mathrm{~kg} / \mathrm{ha})$. 
The plots were regularly weeded to prevent competitive effects of the weeds. For proper data collection, three representative plants from the middle row of each plot were randomly selected and tagged. From the tagged plants, morphological parameters like number of leaves per plant and vine length per plant were recorded five weeks after fertilizer application. At final harvest (three months after planting), leaves of the sampled plants were collected and prepared for laboratory analysis to extract their phosphorous contents by Bray No 1 method and determine the amount of phosphorus by molybdenum blue method (Kuo, 1996).

The data collected were statistically analysed using analysis of variance (ANOVA) with the aid of GENSTAT statistical package and significant means were separated using least significant difference (LSD) at 5\% probability level.

\section{RESULTS AND DISCUSSION}

Single super phosphate (SSP) released higher phosphorus than any other P-fertilizer used. On the other hand, the least phosphorus release was recorded from crystallizer fertilizer treated soil (Figure 1). The longest vine production was favoured by crystallizer while the control plot had the shortest vines (Figure 2). Crystallizer produced the longest vine and consequently the highest number of leaves while the control that had the shortest vine produced the lowest number of leaves (Figure 3). At harvesting, the highest mean mass of the harvested tubers was recorded from the control plot while the least mean mass was from plots treated with crystallizer (Figure 4). The plants from the soil treated with crystallizer fertilizer had the highest leaf phosphorus uptake. The leaf phosphorus uptake followed the trends of leaf and vine productions. That means the plots treated with crystallizer showed the highest level of phosphorus uptake through their leaves. In the same vein, the plots with the lowest number of leaves per plant (control plots) came out with the lowest phosphorus uptake (Figure 5). This implies that the more the vegetative parts (leaves etc.), the more the phosphorus uptake. Moreover, the plots with no phosphorus fertilizer treatment (control) did not show any appreciable vegetative growth (Figures 3 and 4). Despite this observation, the control plots had the highest tuber yield $(193 \mathrm{~kg} / \mathrm{ha})$. The trend of phosphorus release among the fertilizers used in this experiment showed that single superphosphate released the highest level of phosphorus into the soil. It is evident from this result that single super phosphate (the highest phosphorus releaser) is a potential fertilizer capable of correcting phosphorus deficient soils. However, the level of phosphorus release was not directly proportional to $\mathrm{P}$ availability and uptake by the plant leaves. This could be because when higher amount of phosphorus is released, recovery of P-fertilizer by crop uptake is about $15 \%-30 \%$ while about $60 \%$ of the Pfertilizer is adsorbed or fixed by the soil (Olusola, 2009). Therefore, certain amount of $P$ should be added every year to top the amount already present in the soil. To this end, sweet potato on the soil with highest phosphorus release in this experiment had the least $\mathrm{P}$ uptake. In most soils, despite the fact that there is considerable addition of P-fertilizers to the soil, the amount available for plants is usually low because it is converted to unavailable form by its reaction with the soil constituents (Marschner, 1995).

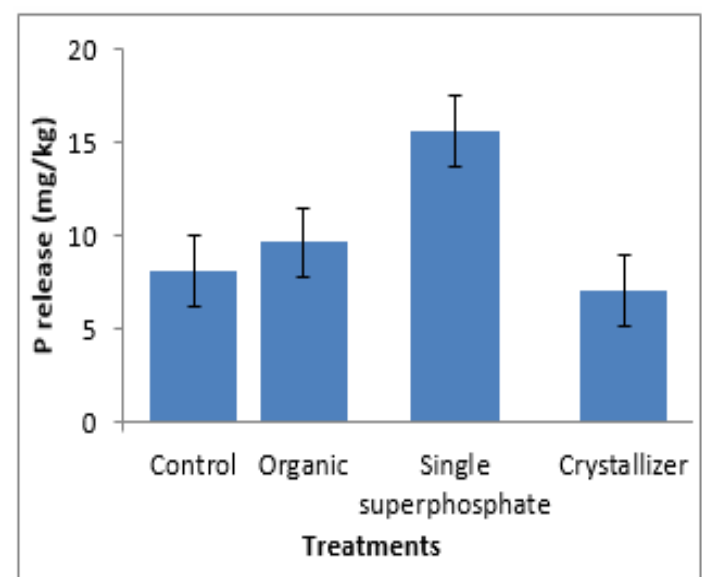

Fig 1: Trend of phosphorus release by different P-fertilizers during incubation study

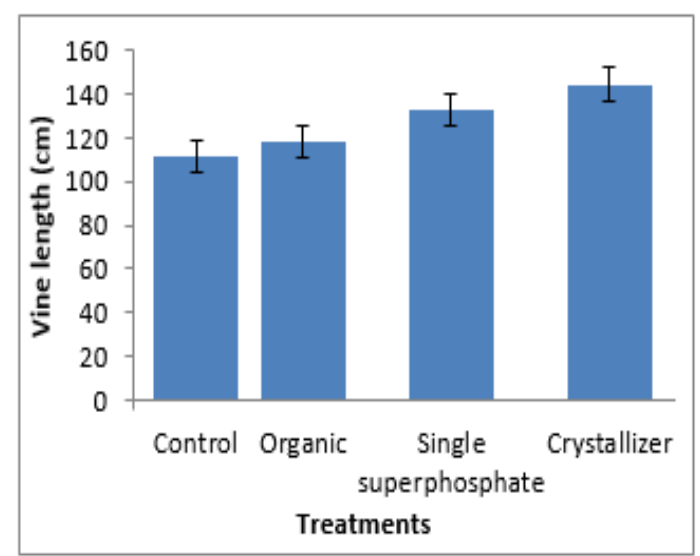

Fig 2: Effect of phosphorus fertilizers on vine length production

The best phosphorus releasing fertilizer among the treatments used (single superphosphate) did not produce the longest vine but the least phosphorus

KAREEM, I; AKINRINDE, EA; OLADOSU, Y; EIFEDIYI, EK; ABDULMALIQ, SY; ALASINRIN, SY; KAREEM, SA; ADEKOLA, OF 
releasing one (crystallizer fertilizer) produced the longest vine. This implies that the more the phosphorus in the soil, the shorter the vine (vegetative part). In the same vein, phosphorus nutrition has been found of being incapable of significantly increasing vine production in sweet potato coupled with the fact that higher phosphorus application would lead to production of shorter vines (Marschner, 1995). It might, therefore, be said that lower level of phosphorus aided cell multiplication which consequently resulted in production of longer vines. It was noted from this experiment that lower phosphorus nutrition through application of Crystallizer fertilizer or any other low-phosphorus releasing fertilizer was beneficial to vegetative success (leaf production) of the sweet potato. This will eventually lead to trapping enough solar energy for higher food production which will be finally translocated to the roots for appreciable tuber development and bulking which are the ultimate targets of crop production. Moreover, leaf production and other vegetative traits were less aided by high phosphorus nutrition. This could be because low level of the nutrient was highly beneficial to the productivity of the plant under consideration (Rashid and Waithak, 2009). Furthermore, longer vine production resulting from application of higher proportion of farmyard manure in combination with lower proportion of $\mathrm{P}$ indicates that sweet potato benefited little from $P$ to increase its canopy compared to the benefit that it derived from farmyard manure (Abdissa, 2012).

The effect of high P-releasing fertilizers on tuberous yield of sweet potato was completely different from the expected result which is: the more the phosphorus in the soil, the more the tuberous yield. This is so because high phosphorus level in the soil suppressed tuber development of sweet potato and other root and tuber crops (FAO, 1994). This is the reason for having very little mention of phosphatic fertilizers being used to benefit sweet potato in the literature. This was perhaps due to lack of yield response of sweet potato to phosphorus nutrition. Also, phosphorus does not appear to be an important nutrient for sweet production though phosphorus is usually recommended in the fertilizer mixture. That was why it was said that elimination of phosphorus from sweet potato nutrition would not affect its yield in the least (FAO, 2005). Low tuberous yield from high phosphorous nutrition can further be attributed to nutrient imbalance that resulted from additional phosphorus nutrition through fertilizer application. Finally, bulking of the tuberous root as well as grain filling in cereals requires lots of potassium nutrition and not high level of phosphorus which if at all is present should be at a minimal level.

The level of vegetative growth (number of leaves and vine length) was found to play a significant role in the level of phosphorus uptake. This implies that there is positive correlation between $\mathrm{P}$ uptake and the number of leaves produced by sweet potato plants. So, the fertilizer which aided higher leaf production directly encouraged the highest phosphorus uptake. In essence, when there is high vegetative production there will be effective absorption of available phosphorus in the soil and phosphorus fixation might be dramatically reduced.

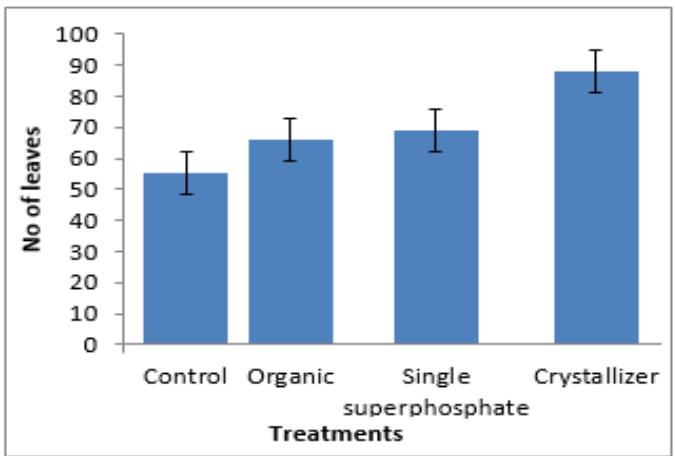

Fig 3: Effect of phosphorus fertilizers on sweet potato leaf production

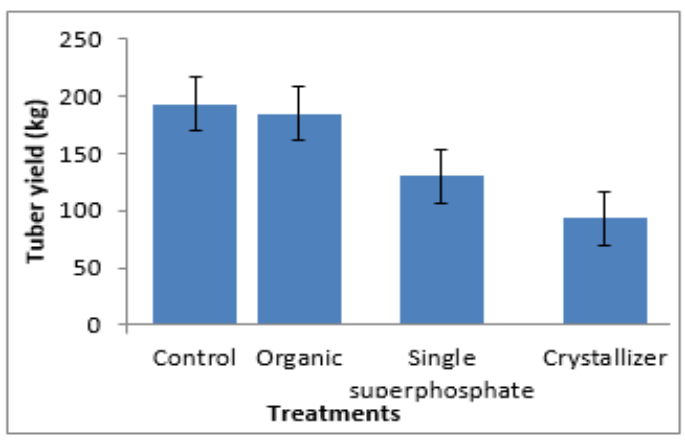

Fig 4: Effect of phosphorus fertilizers on tuber yield of sweet potato 


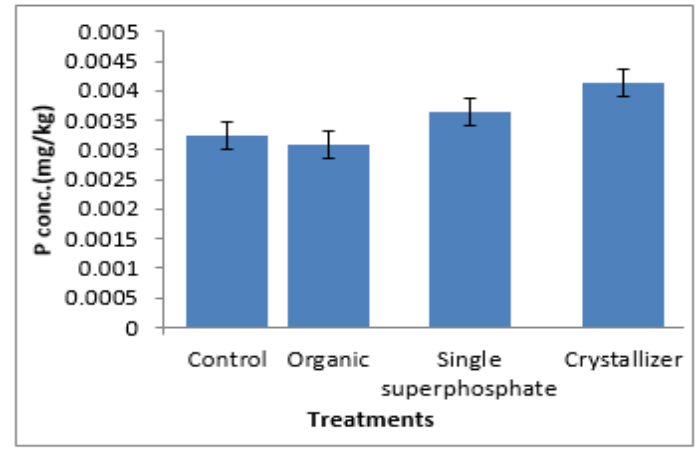

Fig 5: Effect of phosphorus fertilizers on leaf phosphorus uptake of sweet potato

Conclusion: Crystallizer applied at the rate of $500 \mathrm{~kg} / \mathrm{ha}$ can be used for significant phosphorous uptake which equally leads to better quality sweet potato tuber production and appreciable vegetative growth. Also, low soil phosphorus, as low as $6.80 \mathrm{mg} / \mathrm{kg}$, can be used to achieve high tuberous yield in sweet potato. Therefore, soil $\mathrm{P}$ should be maintained as low as $6.80 \mathrm{mg} / \mathrm{kg}$ for better tuberous yield in sweet potato production

\section{REFERENCES}

Abdel-Fattah, AE; Abdel-Hamed, AM (1997). Effect of phosphorus and sulphur application on sweet potato (Ipomoea batatos L.) plant production. $J$. Agric. Sci. Mansoura Univ. 22 (3): 883 - 890.

Abdissa, T; Dechassa, N; Alemayehu, Y (2012). Sweet potato growth parameters as affected by farmyard manure and phosphorus application at Adami Tulu, Central Rift Valley of Ethiopia. Agric. Sci. Res. J. 2(1):1-12

EI-Gamal, AM; Abdel-Nasser, G (1996). Response of sweet potato crop to phosphorus and potassium fertilization rates. Fourth Arabic Conf. Minia, Egypt, 1996. Faculty of Agric. Saba Bacha, Alex. Univ., 25-28 (3): 471-488.

FAO (1994). Tropical root and tuber crops: Production, perspective and future prospect. Food and Agricultural Organization (FAO).Plant Production and Protection Paper, p. 126-228

FAO (2005). Fertilizer use by crop in Ghana. Food and Agriculture Organization of the United Nations (FAO). Food and Nutrition Series. No 28. 190p

Fixen, P E; Vivekananda, M (1990). Effect of large manure application on soil $\mathrm{P}$ intensity. Comun. Soil Plant Analysis. 21: 287 - 293.
Forbes, J C; Watson, D (1994). Plant in Agriculture. Cambridge University Press. First Published in 1992, Reprinted in 1994.

Griffiths, H R; Lunec, J (2001). Ascorbic acid in the 21st Century-more than a simple antioxidant. Enivron. Toxicol, and Pharmacol, 10: 173-182

International Fertiliser Industry Association. 2006. Total fertiliser consumption statistics by region from 1970/71 to 2005/06. http://www.fertilizer.org/stats.htm

Kuo, S (1996). Phosphorus. In: D. L. Sparks (Editor) Pp 869 - 920. Methods of Soil Analysis Part 3 Chemical Methods, SSSA Book Series 5, Madison,Wisconsin, USA.

Lenne, JM (1991). Diseases and pests of sweet potato: South East Asia, the pacific and east Africa. Natural Resources Institutes Bulletin 46(7):116.

Marschner, H (1995). Mineral Nutrition of Higher Plants. 2 nd Ed. Academic Press, Harcourt Brace and Company, Publishers. London, New York, Tokyo, pp 864.

McLaughlin, MJ; Fillery, IR; Till, AR (1991). Operation of the phosphorus,sulphur and nitrogen cycles. In Australia's Renewable Resources: Sustainability in Global Change, ed. R.M. Gifford and M.M. Barson, pp. 67-116. Canberra, Australia: Bureau of Rural Resources.

Nyle, C B; Ray, R W (1999). The Nature and Properties of soils, 12 th ed. (New York: Macmillan).The Role of Phosphorus in Agriculture. (Madison, Wis.: Amer. Soc. Of Agron.)

Olusola, OA (2009). Understanding soil and plant nutrition. Salman Press \& Co. Nig. Ltd, Keffi, Nassarawa State, Nigeria

Purekar, PN; Singh, RR; Deshmukh, RD (1992). Plant Physiology and Ecology. 2nd Ed. S Chand, and Company, New Delhi, India.

Rashid, K; Waithaka, K (2009).The effect of phosphorus fertilization on growth and tuberization of sweet potato, Ipomoea batatas L. ISHS Acta Horticulturae 153: IX African Symposium on Horticultural Crops http://dx.doi.org/10.17660/ActaHortic.1985.153. 47. 